\title{
Dental Implantology: From Titanium to Zirconia Ceramic
}

\section{Khiari $\mathrm{A}^{* 1}$, Hadyaoui $\mathrm{D}^{2}$ and Cherif $\mathrm{M}^{2}$}

${ }^{1}$ DDM, Department of Fixed Prosthodontics, Faculty of Dental Medicine, Monastir, Tunisia

${ }^{2}$ Philosophic doctors, Department of Fixed Prosthodontics, University of Dental Medicine, Monastir, Tunisia

*Corresponding author: Khiari A, DDM, Department of Fixed Prosthodontics, Faculty of Dental Medicine, Monastir, Tunisia, Tel: +216 559678 60; +216986763 49, E-mail: amina_khiari@hotmail.fr

Citation: Khiari A, Hadyaoui D, Cherif M (2015) Dental Implantology: From Titanium to Zirconia Ceramic. J Dent Oral Care Med 1(3): 301. doi: 10.15744/2454-3276.1.301

Received Date: September 20, 2015 Accepted Date: November 04, 2015 Published Date: November 05, 2015

The successful use of zirconia ceramics for the fabrication of tooth-supported restorations has encouraged clinicians to extend its application for implant-supported restorations. CAD/CAM technology in combination with zirconia ceramic has increasingly gained popularity in implant dentistry [1]. Zirconia implants were introduced into dental implantology as an alternative to titanium implants. Zirconia seems to be a suitable implant material because of its opacity, mechanical properties, biocompatibility, and low plaque affinity.

Apical bone loss and gingival recession associated with implants often uncover portions of the metal implant, revealing a bluish discoloration of the overlying gingiva. The use of zirconia implants avoids this complication and accedes to the request of many patients for metal-free implants. The inflammatory response and bone resorption induced by ceramic particles are less than those induced by titanium particles, suggesting the biocompatibility of ceramics [2].

Today, the majority of implant manufacturers offer zirconia abutments for aesthetic implant-supported restorations. Abutments are available in prefabricated or customized forms and can be prepared in the dental laboratory either by the technician or by utilizing CAD/ CAM techniques. The biocompatibility of zirconia toward soft connective and epithelial tissue is essential [1]. Moreover, Y-TZP abutments may promote soft tissue integration, while favorable peri-implant soft tissues may be clinically achieved adjacent to zirconia abutments and zirconia healing caps.

Besides strength considerations, Y-TZP implant abutments offer metal-like radiopacity for better radiographic evaluation, and, ultimately, reduced bacterial adhesion, plaque accumulation and inflammation risk. A systematic review revealed that zirconia abutments could maintain an equivalent bone level in comparison to titanium, gold and aluminum oxide ones [3]. In a randomized controlled trial, 20 customized non HIPed-based zirconia single-tooth implant abutments and 20 customized titanium singletooth implant abutments were followed for 3 years, with no fractures or loosening of abutments in both group and a $100 \%$ survival rate reported [4].

\section{References}

1. Guess PC, Att W, Strub JR (2012) Zirconia in fixed implant prosthodontics. Clin Implant Dent Relat Res 14: 633-45.

2. Özkurt Z, Kazazoglu E (2011) Zirconia dental implants: a literature review. J Oral Implantol 37: 367-76.

3. Koutayas SO, Vagkopoulou T, Pelekanos S, Koidis P, Strub JR (2009) Zirconia in dentistry: part 2. Evidence-based clinical breakthrough. Eur J Esthet Dent 4: 348-80.

4. Zembic A, Sailer I, Jung RE, Hammerle CH (2009) Randomized-controlled clinical trial of customized zirconia and titanium implant abutments for single-tooth implants in canine and posterior regions: 3-year results. Clin Oral Implants Res 20: 802-8.

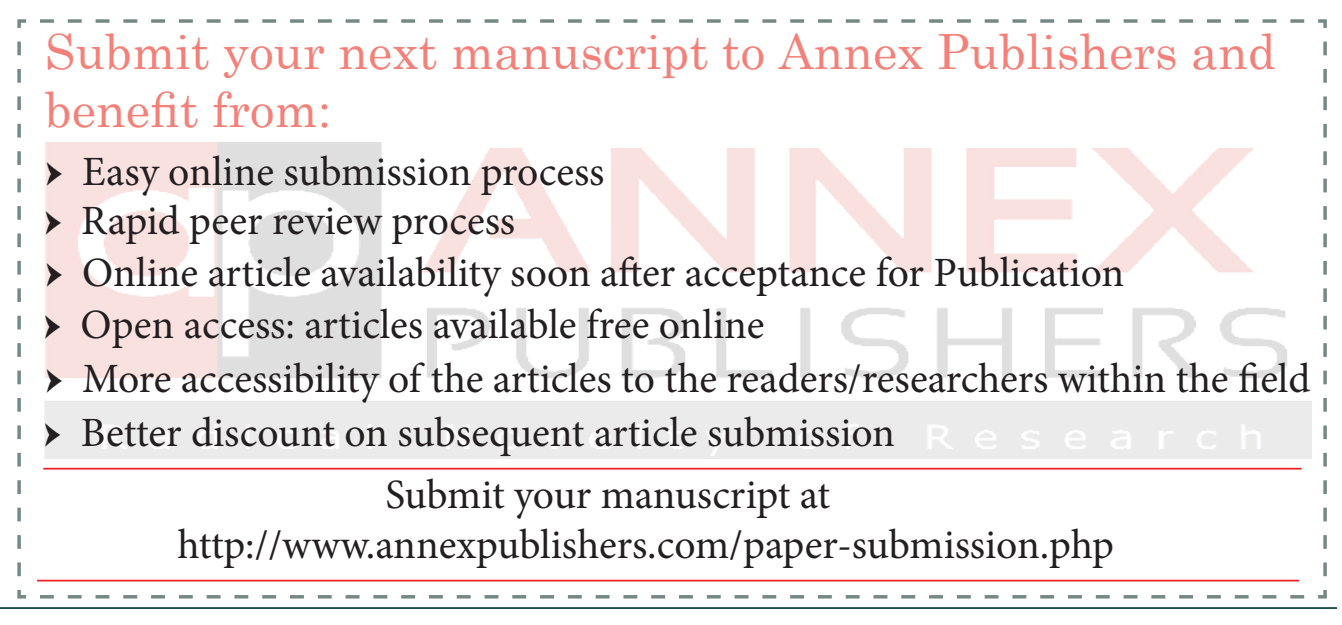

